(C) Ю.А. Стадник

\title{
НАРОДНЫЕ ЗНАНИЯ СЕМЕЙСКИХ БУРЯТИИ О СИМПТОМАХ БОЛЕЗНЕЙ
}

Несмотря на достижения научной медицины, в ХХІ веке этнографы продолжают фиксировать информацию об обращениях русских к знахарям. Современная традиционная народная культура демонстрирует востребованность у русского народа лечения магическими способами. Соответственно возникает вопрос, как люди определяют, к кому им нужно обратиться за помощью, $\kappa$ знахарю или к врачу? На какие признаки своего самочувствия они ориентируются? Симптомы болезней в данном этнологическом исследовании рассматриваются в качестве компонента традиционной народной культуры русских. Такой подход предпринят для того, чтобы сравнить народно-медиичинскую культуру старообрядиев Бурятии (семейских) с другими традициями русских европейской части России в сфере знаний признаков болезней, излечиваемых знахарями. При сравнении выяснилось, что обнаруженные в 90-е годы ХХ века народные знания семейских о симптомах часто аналогичны общерусским, наблюдавшимся этнографами и врачами в конце XIX-начале XX веков. Известные старообрядиам Бурятии симптомь болезней по своей информативности бывают двух видов. Исходя из видовой принадлежности симптома, болезни, излечиваемые у семейских магией, подразделяются на две группь: физически явнье и материально неощутимые. Изучение знаний о симптомах также показало разнииу между традиционной народной культурой и научной медищиной в родо-видовом соотночении болезней и в том, какие состояния считаются заболеваниями.

Ключевые слова: народная медицина, симптомы, старообрядчество, семейские, русские

Ссылка при цитировании: Стадник Ю.А. Народные знания семейских Бурятии о симптомах болезней // Вестник антропологии, 2021. № 2. С. 144-156.

В общеизвестном исследовании Г.И. Попова по русской народной медицине про традиционные знания о признаках заболеваний говорится следующее: «Народная симптоматология, в строгом смысле этого слова, не существует, так как названия болезней, в большинстве случаев, почти всецело исчерпывают в то же время и их симптомы. Народная симптоматология может быть рассматриваема только как совокупность тех своеобразных выражений, которыми народ определяет свои ненормальные ощущения и характеризует те или другие болезненные явления. Представляя интерес с точки зрения способности мужика анализировать свои ощущения, все

Стадник Юлия Александровна - старший преподаватель кафедры хореографического искусства, Санкт-Петербургский Гуманитарный университет профсоюзов (192238 Санкт-Петербург, ул. Фучика д.15). Эл. почта: semeyskaya@bk.ru 
эти определения отличаются большой субъективностью, объективность же их почти всегда имеет суеверный источник» (Попов 1903: 177).

Наблюдения Г.И. Попова подтверждены во второй половине XX века лингвистическим исследованием В.А. Меркуловой. Изученные ею народные названия (около $400)$ болезней на материале говоров русского языка показали, что «в народной медицине квалифицируются не болезни в современном понимании этого слова, а болезненные симптомы, состояния, которые имеют внешнее проявление (жар, судороги, обморок) и субъективные ощущения больного (грудь заложило, в ухе стреляет, в голове обнос и т.д.)» (Меркулова 1980: 168).

Отождествление в традиционной русской народной медицине симптомов с заболеваниями объяснила в XXI веке Е.И. Кириленко в лингвокультурологическом исследовании названий болезней, присутствующих в словаре В.И. Даля. «Особого комментария требует обилие названий кожных заболеваний. В традиционном сознании внешнее описание преобладает над выявлением скрытых характеристик, что соответствовало уровню развития медицинских знаний, ориентированному на симптоматическое лечение, “по одним внешним признакам”. < ..> Симптоматический подход неизбежно предполагает обращение ко внешним, телесным, кожным проявлениям заболеваний, собирая в одном ряду симптомы разных болезней. < ..> Сами причины кожных заболеваний могут быть различны: от многочисленных внешних воздействий (механическое воздействие порождало мозоли, желваки, желуди, задубье, пупыри; крестьянин-земледелец сталкивался с растениями с раздражающим действием и др.) до заболеваний внутренних органов, нарушений обменных процессов. По-видимому, низок был уровень бытовой гигиены» (Кириленко 2012: 30-31).

Знания семейских о симптомах болезней тоже подтверждают мнение Г.И. Попова.

Семейскими называют локально-конфессиональную группу русских старообрядцев, проживающих в Забайкалье. Семейских подразделяют на две подгруппы: 1) семейских, проживающих в Бурятии; 2) семейских, проживающих в Красночикойском районе Забайкальского края (ранее Читинской области). Эти подгруппы отличаются друг от друга по антропологическим и диалектологическим признакам, в материальной и духовной культуре.

Фактологическими источниками для статьи послужили экспедиционные сведения, собранные автором у семейских Бурятии в местах их компактного проживания (Тарбагатайском и Мухоршибирском районах) и литературные источники.

Издавна старообрядцами Забайкалья практиковались разные лечебные способы. В 90-е годы XX века у семейских продолжало бытовать лечение магическими приёмами. При помощи магии принято лечить только определённый класс болезней. Например, чтобы избавиться от простуды, забайкальским старообрядцам заговор не требуется. Среди известных архивных и опубликованных материалов по семейским отсутствуют тексты от лихорадки (простудных заболеваний). Хотя в других русских традициях такие заговоры есть. В прошлом семейские лечились от простуды травами. Ниже пойдёт речь только о симптомах тех болезней, для излечения от которых применяются преимущественно нерациональные, с научно-медицинской точки зрения, способы.

Здесь и далее используются названия заболеваний, принятые у семейских. Если в литературных источниках встретилось название соответствующей болезни на русском или латинском языке, принятое в научной медицине, то оно следует за народным термином и находится в круглых скобках. Выяснение того, с какими болезня- 
ми, известными медикам, соотносятся болезни, известные семейским знахаркам, не является целью и задачей данного этнологического исследования. Такая постановка вопроса ближе историкам медицины, имеющим профессиональное медицинское образование, то есть обученным диагностике заболеваний. Поэтому в данной статье научно-медицинскими названиями сопровождены не все народные термины семейских, обозначающие болезни. Названия болезней семейских пояснены научными эквивалентами преимущественно тогда, когда есть информация об этом в статьях дореволюционного врача В.Ф. Демича, изучавшего русскую народную медицину и имевшего опыт общения с пациентами из рабочей и крестьянской среды. Попутно скажем, что изучение народных названий болезней тоже не входит в задачи данной научной работы, как у В.А. Меркуловой (Меркулова 1969, 1972, 1975, 1980, 1989) или Е.И. Кириленко (Кириленко 2012).

Забайкальские старообрядцы магическими средствами лечат «боли в руках», «водянку», «грыжу», «клин», «зубную боль», «испуг/переполох», «килу», «ко́лотти»/ боли в животе, «криксы/крикты», «от крови»/наружное кровотечение/порез, «огник», «порчу», «пуп новорожденного», «рожу», «сглаз», «собачью старость» (рахит), «утин» (радикулит), от «тоски», от «худого», «щетинку», «ячмень» (ПМА). По литературным источникам известно, что в прошлом семейские лечили ещё от «ночницы» (Ровинский 1873: 123), от «лишая», от «колотья в боках», от «залома» (Воскобойников 1930: 82-84), от «родимца», от «сухой жабы», от «укуса змеи», «волосец» (Болонев 1986: 122-125). Кроме перечисленных болезней старообрядцам Бурятии были известны «сучье вымя» и «хомут» (ПМА).

Далее рассматриваются сведения, полученные от семейских Бурятии о признаках некоторых из перечисленных болезней и, по возможности, комментируются при помощи информации из литературных источников. Традиционные знания семейских о признаках (симптомах) болезней основываются на их реальных наблюдениях и ощущениях. Во время экспедиционной работы редко удаётся встретить людей, на данный момент страдающими от болезней, которые излечивают знахари. Тем более, что этнограф чаще общается с теми, кто лечит, а не с теми, кто болеет. У автора не было возможности увидеть, как выглядят, например, редкие болезни «рожа» и «собачья старость». Поэтому о признаках болезней приходилось подробно расспрашивать в ходе интервью: в каком месте возникает заболевание; имеются ли внешние симптомы на поверхности кожи; наблюдаются ли изменения в поведении больного человека; какое у него настроение; что чувствует заболевший; как он объясняет знахарю свой недуг.

На основе полученных от семейских сведений о традиционных знаниях симптомов возможно разделение болезней на группы. Какой-либо народной классификации болезней по симптомам в культуре старообрядцев Забайкалья не выявлено. В общении со знахарками иногда проскальзывало их отношение к тому или иному заболеванию в зависимости от сложности его лечения. В понимании семейских знахарок сложность заключается в продолжительности курса лечения (сколько требуется лечебно-заговорных сеансов) и, вероятно, в степени страданий заболевшего. От болезней «чирий» и «ячмень» избавляются в течение трёх сеансов. Поэтому к ним относятся как к пустяку. Для излечения от болезней «рожа» и «худой» (порча) традиция может рекомендовать двенадцать сеансов, при этом больной очень плохо себя чувствует. Понятно, что такие заболевания считаются у семейских тяжёлыми. На основании продолжительности лечебного курса и степени нездоровых ощущений болезни могут быть подразделены на 
лёгкие и тяжёлые, хотя сами семейские таких терминов по отношению к изучаемым здесь болезням не употребляют. Очевидно, что в разряд тяжёлых попали совершенно разные по симптомам болезни: «рожа», проявляющаяся наружно локально, и «худой», имеющий общее сильное недомогание. Возможно, эти болезни объединяет не только продолжительность лечебно-магического курса.

Изначально для данного исследования в экспедициях при сборе фольклорно-этнографического материала акцент был сделан на ту информацию, которая имеет отношение к магическим способам лечения. Выяснилось, что при помощи магии лечатся только определённые болезни. Поэтому о других нездоровых состояниях, например, простудных, излечиваемых семейскими, преимущественно, рациональными средствами, у автора сведения отсутствуют. Во время интервью вопросов о таких заболеваниях забайкальским старообрядцам специально не задавалось и сами семейские случайно о них не рассказали.

Обнаруженные в народно-медицинской культуре семейских Бурятии симптомы болезней, излечиваемых магией, по своей информативности бывают двух видов:

- указывающие на отклонения от нормы в материальной (телесной) составляющей человека;

- характеризующие нарушения духовной составляющей человека (его настроение и поведение).

Исходя из перечисленных разновидностей симптомов, болезни, поддающиеся у семейских магическим способам лечения, могут быть подразделены на две группы, соответственно: 1) физически явные; 2) материально неощутимые.

К физически явным недугам относятся болезни, которые обычно можно увидеть невооружённым взглядом и/или имеющие боли, локализующиеся в каком-либо участке организма человека. Большинство из таких болезней проявляется на поверхности в виде нарыва, раны, покраснения, опухоли, увядшей кожи. Единственное заболевание первой группы, при котором изменяется внешний вид всего больного это «собачья старость» (рахит). Вся кожа новорожденного выглядит как у пожилого человека, старика. «Худенький рос, слабенький. <..> Сам он - ладненький, а как старый» (ПМА 6).

Болезнь с народным названием «собачья старость» была зафиксирована этнографами в разных губерниях/областях России. По мнению врача В.Ф. Демича, под таким названием может подразумеваться не одно заболевание, известное научной медицине. «Если ребёнок заметно худеет, по народному выражению, “сохнет весь”, будь это от рахита, хронической бугорчатки, плохого кроветворения, или от другой подобной причины, простолюдинки видят в таких случаях особенную болезнь - “стень”, или “собачью старость", <...> Во многих местностях "стенью” называется сухотка детей (Atrophia infantum). Дитя, страдающее ею, считается не земным жильцом» (Демич 1891: 199). У другого автора, Г.И. Попова находим, что «собачья старость» может иметь название «седун» (английская болезнь, то есть рахит) (Попов 1903: 42).

Сообщений от забайкальских старообрядцев о болезни «волосец» автору не встретилось. О существовании этого заболевания у семейских свидетельствует Ф.Ф. Болонев (Болонев 1986: 122-125). Болезнь под названием «волос» известна во многих других областях. Например, в Курском Посемьи так называют нарывы на ногтях пальцев рук и ног, сопровождающиеся сильной болью. Подобные нарывы В.Ф. Демич определил как panaritium/panaricium/панариций (Демич 1901: 435). По 
аналогии с информацией из других регионов, наверно, семейский «волосец» возможно отнести к разряду физически явных заболеваний.

В этой группе болезней рассматривается и «грыжа»/Hernia, встречающаяся преимущественно у детей в нижней части тела. Повсеместно, в традиционной культуре, это заболевание характеризуется болезненным припадком (грызущей болью) с опухолью или без неё (Высоикий 1911: 43; Демич 1891: 203). Знания русских крестьян о симптомах данного недуга В.Ф. Демич описывал так: «Не менее важная болезнь детей в глазах народа - “грыжа”. Под нею понимают, как то, что следует, так и всякую боль в животе, особенно у детей, когда они беспрестанно кричат, “сучат” ножками и при этом страдают поносами и другими неправильностями пищеварения. <..> По-видимому, простолюдин называет “грыжею” всякую болезнь, при которой что-то мучит, “грызёт” человека» (Демич 1891: 201-202).

Семейские, как и другие русские, подразделяют «грыжу» на виды по расположению места поражения. «Грыжа бывает внутрення, боло́нева, есть пуповая, есть яичная» (ПМА 7). По сообщению В.Ф. Демича “грыжа внутренняя"/“грыжа на животе” - это катарры у детей (поносы) (Демич 1891: 203). Этот же автор обнаружил, что русские в Череповецком уезде (ныне Вологодская область) «болоньями» называли невоспалительные опухоли, проявляющиеся наружно, например, Atheroma, и рассматривал их как заболевания кожи (Демич 1901: 343). В словаре В.И. Даля говорится, что «блона, ж., болона́ < .. > Расплывшийся нарост, опухоль; < ..> кила, грыжа < ..> Бо́лонь восm.-сиб. брюшная часть говядины, брюшное, тонкое, худое мясо < .. >» (Даль 1995: 98). Комментария от семейских о том, что такое «болонева грыжа» и чем она отличается от других разновидностей, не зафиксировано. Опираясь на В.И. Даля, допустим, что такой вид грыжи может иметь отношение к мышцам живота.

В очерке В.Ф. Демича о хирургии у русского этноса сообщается, что «весьма важна у народа г р ы ж а, под которою простолюдины понимают многие, самые разнообразные заболевания. В старину слово г р ы ж а употреблялось в смысле глагола грызть, то есть ныть, ломить. Под г ры же й разумели боль, ломоту, но не выхождение внутренностей <..>. Грыжа, в хирургическом значении (Hernia), называлась тоже г р ы ж е й, но не в смысле опухоли, которая, при образовании небольшого грыжевого мешка, звалась килой, а в смысле боли» (Демич 1911: 1611-1612). Представления о «грыже», как о чём-то грызущем в разных частях организма, включая хронический ревматизм, заболевания суставов, сухожильных влагалищ, костей, опухоли, нарывы, сыпи (Демич 1911: 1611-1612, 1614), у семейских в 90-х годах XX века замечено не было. В заговорно-заклинательных текстах от грыжи забайкальских старообрядцев есть перечисления видов этой болезни: «Заедаю я грызь у раба Божиего младенца (имя) пуповую, паховую, глазную, жиловую» (ПМА 3); «Грыжа нутряная, грыжа пуповая, грыжа паховая, подите в лес» (ПМА 2). В двух других заговорах семейских от «грыжи» указывается топография болезни: «Не грызи, грыжа, у пупа» (ПМА 8); «Так же раба Божиего (имя), грыза, по животу не ходить» (ПМА 1). Только однажды была названа глазная «грыжа». В большинстве случаев в заговорно-заклинательных текстах семейскими были названы пупочная и паховая разновидности «грыжи». Отвечая на вопросы во время интервью, семейские знахарки говорили о «грыже» тоже, как о заболевании в области живота или паха. Вероятно, как и у русских повсеместно, в отдалённом прошлом у забайкальских старообрядцев название «грыжа» включало в себя разнообразные болезни, объединённые характером боли. К концу 
$\mathrm{XX}$ века в народно-медицинской традиции семейских уже́ наблюдалось совпадение понятия «грыжа» с научно-хирургическим заболеванием Hernia.

Помимо паховой «грыжи» семейские ещё выделяют болезнь «клин». Знахарке, от которой было записано лечение от «клина», известно и лечение от «грыжи». Информатор распознавала эти болезни у детей по внешнему виду мужских половых органов. При «грыже» «яичко бывает светлое-светлое» (ПМА 7). «Клином» страдают новорожденные мальчики. При этом заболевании одно яичко увеличивается (ПМА 7). Из комментариев знахарки понятно только то, что она различает паховую «грыжу» и «клин». Обратимся за объяснениями к научной медицине. По одной из классификаций, основанной на величине и положении грыжевого мешка, все паховые грыжи делятся на три вида:

1. собственно паховая грыжа: мешок находится исключительно в паховом канале;

2. пахово-мошоночная канатиковая грыжа: мешок опускается в мошонку, но не достигает яичка;

3. пахово-мошоночная яичковая грыжа: мешок спускается в мошонку и достигает яичко, может располагаться вокруг него (Паховая 2014).

Вероятно, «клином» семейские называют третий вид паховой грыжи. Этот пример показывает ещё и разницу в восприятии того или иного состояния больного человека в народной и научной медицине. Две разные болезни «клин» и паховая «грыжа», с точки зрения традиционной медицинской культуры, в научной медицине выступают в качестве разновидностей одного заболевания.

По мнению семейских, болезнь «кила» представляет собой нарыв: у женщин на лице, у мужчин на половых органах (ПМА 10). В русской народной медицине «килой» называются большие гнойные фурункулы (Харитонова 1999: 257). Врач В.Ф. Демич определял «килу» как «затвердевшую опухоль на частях тела, не защищённых одеждою» (Демич 1911: 1609). Далее он уточнил, что в русской народной терминологии под именем «килы» могут подразумеваться, кроме опухолей, ещё грыжи и нарывы (Демич 1911: 1610). Такие опухоли возникают «на “п р и т о ш н ы х” местах - на лице, в горле, в заднем проходе и на половых органах. К и л о ю называются также всякие наружные воспалительные опухоли, особенно скоротечные нарывы» (Демич 1911: 1610-1611). В представлениях семейских болезнь «кила» дифференцирована от грыжи, чирьев, ячменя.

Болезнь «огник» появляется на лице в виде водянистых пузырьков. «Огник бувает, больки мокрые тут» (ПМА 5: 49). В других регионах России так могут называть прыщи на губах и языке (стоматит и/или герпес) и сыпь на лице (Демич 1901: 342, 346; Попов 1903: 43; Огник 2014). Судя по объяснениям знахарки, семейским известен «огник» только во втором значении. По диагностике В.Ф. Демича, данное народное название болезни соответствует в научной медицине такому заболеванию кожи как мокнущий лишай/еczema (Демич 1901: 343).

Со слов семейских, болезнь «рожа» - опухоль на коже, имеющая красный оттенок и свойство раздуваться. Кроме этого, при «роже» больное место зудится. Рожистая опухоль может появиться в любом месте на поверхности кожи. «Рожа глубоко мышечное заболевание, опухшее, красное, опухоль. Большая температура. Человека знобит. Если запущена, возникает постоянный зуд, гнойники. Распространяется к сырому месту (ко рту, глазам), а если на теле - то в потливых местах. <..> 12 рож - красная, чёрная, ве́тренная, хропуша (давит человека)» (ПМА 9). По мне- 
нию В.Ф. Демича, в русской традиционной народно-медицинской культуре термином «рожа» может называться как известное научной медицине заболевание рожа (erysipelas), так и «многие другие воспалительные болезни, как флегмона, лимфангоит и тому подобное» (Демич 1911: 1618).

Семейским известна болезнь «сучье вымя»/ «сучьи титьки», которая возникает в подмышечной впадине и представляет собой опухоль. «Сучье вымя - подмышки натягивает у детей, у всех. <..> Ну, как титьку натянет» (ПМА 6: 71). Такое заболевание в русской народной медицине встречается повсеместно. По утверждению В.Ф. Демича, «сучьим выменем» русские называют воспаление подмышечных желёз (Демич 1911: 1623). «Сучье вымя» является устаревшим названием болезни «гидраденит». Это заболевание «представляет собой тяжёлое воспаление апокринных потовых желёз, размещающихся в области подмышечных впадин, паха, значительно реже - в области ареолы соска, гениталий, ануса и мошонки» (Сазонов 2020). В народной медицине семейских «сучьим выменем» называется воспаление только в подмышечной области.

Объяснить, как выглядит болезнь «хомут», информаторы не смогли, потому что о ней плохо помнили. На момент общения автора со старообрядцами Забайкалья знахарки, умевшие лечить такую болезнь, уже́ ушли из жизни. Сведения были получены от знахарок, знавших о «хомуте» понаслышке. По мнению семейских, это было тяжёлое заболевание и трудно излечимое. О том, что такое заболевание проявлялось наружно и локально, известно по литературным источникам (Матвеева 1987: 127-139). От нестарообрядческого населения Восточной Сибири было записано, что обычно «хомут» представлял собой красную окружность вокруг туловища или на лице (на носу, на губе). Как будто на человека надет хомут. У больного при этом могли быть зуд, опухоль, нарыв, ощущение удушья. Возможно, что «хомутом» называли опоясывающий лишай.

Болезнью «щетинка» страдают новорожденные дети. Они не могут спокойно лежать на спине, ёрзают, потому что на коже есть остатки остевых волос, которые ассоциируются с щетиной. Наукой установлено, что это явление - обычный атавизм, связанный с внутриутробным развитием человека (Демич 1901: 351). В научной медицине такое состояние кожи младенца не рассматривается в качестве болезни. В народно-медицинской традиции русских, в том числе и семейских, наоборот, «щетинка» новорожденных считается заболеванием.

В Забайкалье, как и повсеместно в России, известны нарывы на разрезах глаз. Такой недуг семейские называют общепринятым в разных регионах словом «ячмень». Научная медицина данную болезнь определяет как hordeolum, то есть «острое гнойное воспаление волосяного мешочка ресницы и сальной железы Цейса, которая располагается около луковицы ресниц. <..> Симптомы <..> воспаление и отёк края века, краснота, болезненность» (Ячмень 2020).

К группе физически явных болезней относятся также «боли в руках», «водянка», «жаба» (зоб), «зубная боль», «ко́лотти», «лишай», наружное кровотечение/порез, рана на пупе новорожденного, «ути́н» (радикулит). Они определяются по болевым ощущениям и/или внешним повреждениям на организме человека.

Ко второй группе относятся болезни, для которых не характерны поражения каких-либо органов и частей тела у человека. Взрослые больные жалуются на плохое душевное состояние и общую слабость. Младенцы беспрерывно плачут. У детей по- 
старше появляется заикание. К материально неощутимым болезням семейских относятся: «испуг/переполох», «криксы/крикты», «порча», «сглаз», «тоска», «худой». В научной медицине перечисленные народные названия недугов могут соответствовать нервно-психическим заболеваниям (Высоцкий 1911: 52; Грысык 1992: 13).

Сведений о кликушах (бесноватых) от старообрядцев Забайкалья автором записано не было. В литературных и архивных источниках по семейским о них информации не встретилось. Возможно, что семейские не знали такую болезнь, как икота. Напомним, что симптомы у кликуш соответствуют истерии (Демич 1889: 1).

«Испуг/переполох» чаще бывает у детей, реже - у взрослых. Согласно научной медицине, более расположены к испугу (неврозу страха) дети младшего возраста (в возрасте до двух лет), а также те, кто слишком заласкан или слишком строго воспитывается. Это явление может выражаться в таких симптомах, как ночные кошмары, хождение и плач во сне, недержание мочи, частый плач, перевозбудимость, заикание, страх одиночества или отсутствия родителей, немотивированный страх перед какими-либо объектами (Испуг 2020). Традиционные народно-медицинские наблюдения старообрядцев Забайкалья за данным заболеванием совпадают с научными. По словам информантов, испугавшись домашнего животного, резкого звука или человека, ребенок плохо спит. Семейские по симптомам «испуг» отличают от «сглаза» и «крикс». Такие больные спят с полуоткрытыми глазами, могут страдать ночным недержанием мочи.

«С.Ю. А как узнать, испугался ребёнок или нет?

Е.Е.А. А он ежели испугался, то он спит, а глаза-то у него открыты, щёлки открыты. Вот, испугался. А по ём видно, он и сикаться начнёт» (ПМА 5:43).

В Курском Посемье считают, что больные «испугом» заикаются. Забайкальские старообрядцы при этой болезни такой симптом, как заикание не назвали. Семейские у данной болезни различают своего рода степени тяжести. «Испуг» бывает маленький и большой (ПМА 4). Соответственно, последний лечится дольше, то есть нужно совершить большее количество лечебно-магических сеансов.

«Криксы/крикты» - по убеждениям семейских, детская болезнь, проявляющаяся в беспрерывном беспричинном плаче у новорожденных. По мнению В.Ф. Демича, «крикливицы» (то же, что и «криксы») - «беспокойное состояние детей от какой-нибудь болезни» (Демич 1891: 207).

Больные «сглазом» всегда жалуются на общее плохое самочувствие. «Начинают зевать, как-то сибе́, ну, в теле не то получается, какое чувство, какой-то вялый делаешься. Заболеешь про́ста-ки» (ПМА 7). О симптомах «сглаза» у Г.И. Попова есть такое описание: «Иногда глазу приписывается лишь лёгкое недомогание - головная боль, соединённая с зевотой, а иногда все болезни внезапные, особенно сопровождающиеся тяжёлым общим чувством и жаром» (Попов 1903: 37). «Славянские древности» о признаках сглаза сообщают следующее: «Человек, которого сглазили, начинает бледнеть, худеть, сохнуть; он жалуется на головную боль, головокружение, потерю сознания, слабость, ломоту во всём теле, тошноту, отвращение к пище и т.п.» (Левкиевская 2009: 599).

При болезнях «порча», «тоска», «худой» больные испытывают сильное общее недомогание, а также у них ухудшается настроение. По симптомам эти болезни и «сглаз» схожи друг с другом. Существенные отличия имеются в представлениях семейских о возникновении этих болезней. 
Сохранившиеся до 90-х годов XX века народно-медицинские знания семейских о симптомах нездорового состояния находят себе аналогии в других региональных традициях русского народа. Это свидетельствует о существовании связи с общей системой традиционных представлений о болезнях. Данная связь позволяет делать предположения на основе общерусского фонда там, где недостаточно сохранились или отсутствуют полностью традиционные знания у старообрядцев Бурятии. С другой стороны, поскольку народные представления семейских о симптомах болезней такие же, как и у русских повсеместно, то в этих знаниях не обнаруживается мировоззренческая этнокультурная самобытность забайкальских старообрядцев. Может быть это обстоятельство связано с тем, что информация была собрана автором в 90-е годы XX века от современных людей, всё-таки отошедших от традиционных народных представлений об окружающем мире. Более ранних сведений о симптоматических знаниях семейских архивные материалы и научная литература не дают.

В своё время В.Ф. Демич заметил, что одним русским народным термином могут быть названы различные в научной медицине болезни (Демич 1911: 1604). Позднее обозначение одним и тем же словом различных заболеваний в русских говорах разных областей России наблюдала и советский учёный В.А. Меркулова. Приведём один из её примеров, «<..> лопу́ха́, лапти́хá, лапту́шка, лапту́шки. Все эти формы используются для обозначения болезней, сопровождаемых сыпью крупными пятнами, лепешками, «лапта́ми». Имеются в виду скарлатина, корь, краснуха, ветрянка, оставляющие редкие следы <...> (Меркулова 1972: 158-159). Судя по рассмотренной выше информации о симптомах грыжи, такое явление было свойственно и семейским Бурятии. Однако, в конце XX века у старообрядцев Бурятии в знаниях о признаках грыжи наблюдалась тенденция сближения народной симптоматологии с научной медициной. Вероятно, это можно объяснить повышением уровня просвещённости у населения по сравнению с рубежом XIX-XX веков.

Изучение народных знаний семейских о симптомах болезней показало, что в русской традиционной культуре отдельно взятого региона различными болезнями могут считаться разновидности одного заболевания (по научным меркам). При этом определяющим фактором является анатомо-топографическое основание, то есть место поражения. Например, в зависимости от расположения грыжевого мешка в области паха семейские диагностируют две разные болезни, «грыжу» и «клин». Или, в научной медицине гидраденит объединяет разные поражённые области тела, а в народно-медицинской культуре семейских разновидность этого заболевания, появляющаяся в подмышечной впадине, воспринимается как отдельная болезнь под названием «сучье вымя». Подобные воспаления потовых желез в других частях туловища забайкальские старообрядцы так не называют. Также очевидно, что для проведения изучения народных знаний семейских о симптомах оказалась существенной первостепенность анатомо-топографического принципа, которую выявила Е.И. Кириленко в ходе лингвистической классификации названий болезней (Кириленко 2012: 8).

В то же время обратим внимание на то, что знания семейских Бурятии о симптомах, записанные в 90-е годы XX века, нашли аналогии в источниках конца XIX начала XX веков. Этот факт свидетельствует об устойчивости бытования некоторых элементов традиционного народного мировоззрения у современных русских.

Проведённое в данном исследовании на основе народной традиционной симптоматологии распределение болезней на физически явные и материально неощутимые 
позволило упорядочить фольклорно-этнографические факты, записанные от семейских. При таком разделении не оказалось случаев пересечения двух групп, то есть не было заболевания, которое могло бы быть отнесено и к первой, и ко второй группе. Поэтому предложенный способ группировки имеющегося материала оправдал себя.

Ориентируясь на перечисленные в статье симптомы, семейские верят в магические способы лечения. С признаками нарушения здоровья забайкальские старообрядцы Бурятии обращаются к бабушкам (знахаркам).

\section{Источники и материалы}

Болонев 1986 - Болонев Ф.Ф. О народной медицине и заговорах русского населения Забайкалья // Генезис и эволюция этнических культур Сибири / отв. ред. И. Н. Гемуев, А.М. Сагалаев. Новосибирск: [Б.и.], 1986. С. 114-129.

Воскобойников 1930 - Воскобойников В. Приметы и суеверия семейских. Бурятиеведение, 1930. № III-IV (11-12). C. 81-84.

Высоикий 1911 - Высоцкий Н.Ф. Народная медицина. Москва: типография Л.В. Пожидаевой, 1911. 168 с.

Грысык 1992 - Грысык Н.Е. О причинах и локализации сглаза, уроков, призоров и некоторых других болезней // IV Соловецкий общественно-политический форум: «Человек и общество, психическое здоровье и экология культуры». Архангельск-Соловки: Издательство Поморского университета, 1992. С. 12-14.

Даль 1995 - Даль В.И. Толковый словарь живого великорусского языка: В 4 т. Т. 1: А-3. Москва: Издательство ТЕРРА, 1995. 800 с.

Демич 1889 - Демич В.Ф. Очерки русской народной медицины (I. Акушерство и II. Гинекология у народа). Медицина (газета для практических врачей), 1889. № 22. С. 1-3; № 23. С. 5-7; № 26. С. 3-6; №32. С. 4-6; № 33. С. 4-7; № 37. С. 5-7; № 38. С. 4-8; №39. С. 1-5; № 40. С. 1-2.

Демич 1891 - Демич В.Ф. Педиатрия у русского народа. Вестник общественной гигиены, судебной и практической медицины, 1891. Т. ХІ. Кн. 2. С. 125-145; Т. ХІ. Кн. 3. С. 187-212; T. XII. Кн. 1. С. 66-76; T. XII. Кн. 2. С. 111-123; T. XII. Кн. 3. С. 169-186.

Демич 1901 - Демич В.Ф. Сифилис, венерические и кожные болезни и их лечение у русского народа. Русский архив патологии, клинической медицины и бактериологии, 1901. Вып. 4. С. 337-364; Вып. 5. С. 423-455.

Демич 1911 - Демич В.Ф. Очерки русской народной медицины. Хирургия у русского народа. Вестник общественной гигиены, судебной и практической медицины, 1911. Кн. 11(ноябрь). С. 1603-1627; Кн. 12 (декабрь). С. 1739-1794.

Испуг 2020 - Испуг. Медицинский портал Tiensmed. Доступ: https://yandex.ru/turbo/tiensmed. $\mathrm{ru} / \mathrm{s} /$ news/ispug 1.html (дата обращения 17.12.2020).

Левкиевская 2009 - Левкиевская Е.Е. Сглаз // Славянские древности: Этнолингвистический словарь в 5-ти томах / под ред. Н.И. Толстого. Т. 3: К (Круг) - П (Перепёлка). 2004 г. М.: Международные отношения, 1995 - 2014. С. 597-602.

Матвеева 1987 - Матвеева Р.П. (отв. ред.). Мифологические рассказы русского населения Восточной Сибири / сост. В.П. Зиновьев. Новосибирск: Наука, Сибирское отделение, 1987. 400 с.

Огник 2014 - Огник. Портал «Изба-Читальня - электронные книги и бесплатные учебники». Доступ: http://uchebnikfree.com/netraditsionnaya-meditsina-populyarnaya/ognik-13643.html (дата обращения 27.07.2014).

Паховая 2014 - Паховая грыжа. Аптека тяньши: Здоровый образ жизни, альтернативная медицина, БАДы. Доступ: http://www.tiensmed.ru/news/pahgrija-r8m.html (дата обращения: 26.07.2014).

ПМА 1 - Полевые материалы автора. № 86. Лечение грыжи. Записали 7.06.1993. Ю.А. Стадник и О.Ю. Фурман в с. Куйтун Тарбагатайского района Бурятии от семейской Власовой Евдокии Ивановны («Савонихи»), 1906 г. р. Дневник № 1. 
ПМА 2 - Полевые материалы автора. №91. Лечение грыжи. Записано 7.10.1999. в с. Десятниково Тарбагатайского района Бурятии от семейской Чистяковой Анны Прокопьевны, 1916 г. р. (уроженки с. Десятниково). Аудиокассета № 14 (А).

ПМА 3 - Полевые материалы автора. №15. Лечение грыжи. Записано 22.07.1997. в с. Заган Мухоршибирского района Бурятии от семейской Никоновой Евдокии Павловны, 1928 г.р. Аудиокассета № 7 (В).

ПМА 4 - Полевые материалы автора. Дневник №3. Записано 23.07.1997. в с. Шаралдай Мухоршибирского района Бурятии от семейской Кравцовой Фёклы Павловны, 1924 г.р.

ПМА 5 - Полевые материалы автора. Дневник №4. Записано 25.07.1997. в с. Шаралдай Мухоршибирского района Бурятии от семейской Евдокимовой Елены Антоновны (в народе - Христиньи), 1935 г.р.

ПМА 6 - Полевые материалы автора. Дневник № 4. Записано 26.07.1997. в с. Шаралдай Мухоршибирского района Бурятии от семейской Карповой Анны Исаковны, 1930 г.р., уроженки с. Новый Заган этого же района.

ПМА 7 - Полевые материалы автора. Дневник № 5. Записано 29.07.1997. в с. Никольское Мухоршибирского района Бурятии от семейской Калашниковой Екатерины Михеевны, 1936 г.р.

ПМА 8 - Полевые материалы автора. № 45. Лечение грыжи. Записано 29.07.1997. в с. Никольское Мухоршибирского района Бурятии от семейской Калашниковой Екатерины Михеевны, 1936 г.р. Аудиокассета № 9 (А). Дневник № 4.

ПМА 9 - Полевые материалы автора. Дневник № 6. Записано 3.05.1998. в с. Никольское Мухоршибирского района Бурятии от семейской Капустиной Валентины Ивановны, 1937 г. p.

ПМА 10 - Полевые материалы автора. Дневник №2. Записано 7.10.1999. в с. Десятниково Тарбагатайского района Бурятии от семейской Чистяковой Анны Прокопьевны, 1916 г.р.

Ровинский 1873 - Ровинский Н.А. Материалы для этнографии Забайкалья (продолжение). Известия Сибирского отделения Императорского РГО, 1873. Т. IV. №3. С. 112-132.

Сазонов 2020 - Сазонов Г.А. Сучье вымя (гидраденит): симптомы, причины, профилактика и методы лечения сучьего вымени. Медицинский портал dr20.ru. Доступ: http://dr20.ru/ kojnye/gidradenit/ (дата обращения: 05.12.2020).

Ячмень 2020 - Ячмень. Википедия. Доступ: https://wiki2.net/\%D0\%AF\%D1\%87\%D0\%BC\%D0\%B5\%D0\%BD\%D $1 \% 8 \mathrm{C} \_$( $\%$ D $0 \%$ B 7\%D0\%B $0 \%$ D0\%B $1 \%$ D0\%BE $\%$ D0\%B$\mathrm{B} \% \mathrm{D} 0 \% \mathrm{~B} 5 \% \mathrm{D} 0 \% \mathrm{~B} 2 \% \mathrm{D} 0 \% \mathrm{~B} 0 \% \mathrm{D} 0 \% \mathrm{BD} \% \mathrm{D} 0 \% \mathrm{~B} 8 \% \mathrm{D} 0 \% \mathrm{~B} 5$ ) (дата обращения: 05.12.2020).

\section{Научная литература}

Кириленко Е.И. Круг болезней в языковом сознании и медицинской традиции русских: опыт классификации по материалам словаря В.И. Даля. Медицинская антропология и биоэтика: Научный, образовательный, научно-популярный журнал. Электронное издание. Доступ: http://jmaib.iea.ras.ru/ru/journal/vypusk-3 (дата обращения: 2.08.2014).

Меркулова В.А. Народные названия болезней, I (На материале русского языка) // Этимология. 1967. Материалы Международного симпозиума «Проблемы славянских этимологических исследований в связи с общей проблематикой современной этимологии», 24-31 января 1967 г. / отв. ред. О.Н. Трубачев. Москва: Наука, 1969. С. 158-172.

Меркулова B.A. Народные названия болезней, II (На материале русского языка) // Этимология. 1970 / под ред. Ж.Ж. Варбот, Л.А. Гиндина, Г.А. Климова, В.А. Меркуловой, В.Н. Топорова, О.Н. Трубачева. М.: Наука, 1972. С. 143-206.

Меркулова В.А. Народные названия болезней в русском языке // Этнографические аспекты изучения народной медицины. Тезисы всесоюзной научной конференции 10-12 марта 1975 г. / отв. ред. Ю.В. Бромлей. Ленинград: Наука, Ленинградское отделение, 1975. С. 56-57.

Меркулова В.А. Народные названия болезней, ІІІ (На материале русского языка) // Древнерусский язык. Лексикология и лексикография / отв. ред. Р.И. Аванесов. М.: Наука, 1980. С. 168-185. 
Меркулова В.A. Народные названия болезней, IV (На материале русского языка) // Этимология. 1986 - 1987 / отв. ред. О.Н. Трубачёв. М.: Наука, 1989. С. 140-152.

Попов Г.И. Русская народно-бытовая медицина: По материалам этнографического бюро князя В.Н. Тенишева. Санкт-Петербург: типография А.С. Суворина, 1903. 404 с.

Харитонова В.И. Заговорно-заклинательное искусство восточных славян: проблемы традиционных интерпретаций и возможности современных исследований. Москва: Институт этнологии и антропологии РАН, 1999. 602 с.

Stadnik, Yulia A.

\section{Folk Knowledge of the Semeyskiye of Buryatia about the Symptoms of Diseases}

DOI: $10.33876 / 2311-0546 / 2021-54-2 / 144-156$

Despite the achievements of scientific medicine, in the XXI century Russians still recourse to healers according to the ethnographic data. Modern traditional folk culture demonstrates the popularity of treatment by magic among the Russians. This raises the question of how people decide whether they should turn to a healer or a doctor. What symptoms are they guided by? The present study considers symptoms of diseases as an element of the traditional Russian folk culture. This approach allows us to compare the folk medical culture of the Buryat old believers (Semeyskiye) with other traditions of Russians of the European part of Russia concerning the diseases cured by healers. It was found that the folk understanding of the symptoms among the Semeyskiye revealed in the 90-s of the XX century is often similar to general Russian knowledge observed by ethnographers and doctors in the end of the XIX century-beginning of the XX century. The symptoms and the diseases known to the old believers of Buryatia that can be cured by magic fall into two categories: physically obvious and materially imperceptible. The study revealed the difference between traditional folk culture and scientific medicine in type and variety of diseases and what conditions are considered diseases.

Keywords: folk medicine, symptoms, old belief, Semeyskiye, Russians

For Citation: Stadnik, Y.A. 2021. Folk Knowledge of the Semeyskiye of Buryatia about the Symptoms of Diseases. Herald of Anthropology (Vestnik Antropologii) 2 (54): 144-156.

\section{Author Info:}

Stadnik, Yulia A. - senior lecturer of Department of choreographic art, Saint-Petersburg University of Humanities and Social Sciences (Saint-Petersburg, Russian Federation). E-mail: semeyskaya@bk.ru

\section{References}

Kharitonova V.I., 1999. Zagovorno-zaklinatel'noe iskusstvo vostochnykh slavian: problemy traditsionnykh interpretatsii $i$ vozmozhnosti sovremennykh issledovanii [Spell and charm art of the Eastern Slavs: problems of traditional interpretations and opportunities of modern research]. Moscow: RAS Institute of Ethnology and Anthropology.

Kirilenko, E.I. 2012. Krug boleznei v yazykovom soznanii i meditsinskoi traditsii russkikh: opyt klassifikatsii po materialam slovaria V.I. Dalia. Meditsinskaia antropologiia i bioetika: Nauchnyi, obrazovatel'nyi, nauchno-populiarnyi zhurnal 3 [Range of diseases in the Linguistic consciousness and medical tradition of Russians: classification experience based on the materials of the dictionary by V.I. Dal. In Medical Anthropology and Bioethics: Scientific, educational, popular science journal]. http://jmaib.iea.ras.ru/ru/journal/vypusk-3 (Accessed 2.08.2014). 
Merkulova, V.A. 1967. Narodnye nazvaniia boleznei, I (Na materiale russkogo yazyka) [Folk names of diseases, I (based on the material of the Russian language)]. In Etimologiia. 1967. Materialy Mezhdunarodnogo simpoziuma "Problemy slavianskikh etimologicheskikh issledovanii v sviazi s obshchei problematikoi sovremennoi etimologii', 24-31 yanvaria $1967 \mathrm{~g}$. [Etymology. 1967. Materials of the International Symposium "Problems of Slavic etymological research in connection with the general problems of modern etymology", January 24-31, 1967], edited by O.N. Trubachev, 158-172. Moscow: Science.

Merkulova, V.A. 1972. Narodnye nazvaniia boleznei, II (Na materiale russkogo yazyka) [Folk names of diseases, II (based on the material of the Russian language)]. In Etimologiia, edited by Zh.Zh. Varbot, L.A. Gindina, G.A. Klimova, V.A. Merkulovoi, V.N. Toporova, O.N. Trubacheva [Etymology. 1970], edited by Zh.Zh. Varbot, L.A. Gindin, G.A. Klimov, V.A. Merkulova, V.N. Toporov, and O.N. Trubachev, 143-206. Moscow: Science.

Merkulova, V.A. 1975. Narodnye nazvaniia boleznei v russkom yazyke [Folk names of diseases in the Russian language]. In Etnograficheskie aspekty izucheniia narodnoi meditsiny. Tezisy vsesoiuznoi nauchnoi konferentsii 10-12 marta $1975 \mathrm{~g}$. [Ethnographic aspects of study of folk medicine. Abstracts of the all-Union scientific conference of March 10-12, 1975], edited by Yu.V. Bromlei, 56-57. Leningrad: Science.

Merkulova, V.A. 1980. Narodnye nazvaniia boleznei, III (Na materiale russkogo yazyka) [Folk names of diseases, III (based on the material of the Russian language)]. In Drevnerusskii yazyk. Leksikologiia i leksikografiia [Old Russian language. Lexicology and lexicography], edited by R.I. Avanesov, 168-185. Moscow: Science.

Merkulova, V.A. 1989. Narodnye nazvaniia boleznei, IV (Na materiale russkogo yazyka) [Folk names of diseases, IV (based on the material of the Russian language)]. In Etimologiia. 19861987 [Etymology. 1986-1987], edited by O.N. Trubachev, 140-152. Moscow: Science.

Popov, G.I. 1903. Russkaia narodno-bytovaia meditsina: Po materialam etnograficheskogo biuro kniazia V.N. Tenisheva [Russian folk and household medicine: based on the materials of the ethnographic Bureau of Prince V.N. Tenishev]. St. Peterburg: tipografiia A.S. Suvorina. 